\title{
ISTORIJSKI INSTITUCIONALIZAM, BALKAN I OSMANSKO CARSTVO ${ }^{1}$
}

\author{
Dušan Čorbić \\ Fakultet političkih nauka, Univerzitet u Beogradu
}

\begin{abstract}
SAŽETAK
Predmet ovog rada jeste pokušaj instrumentalizacije teorijskog pristupa istorijskog institucionalizma na polje razvoja balkanskih država sa ciljem objašnjavanja institucionalnog poretka ovog prostora. Istorijski institucionalizam se otuda može okarakterisati kao pogodan okvir za razumevanje specifičnosti institucionalnog razvoja balkanskih država. Samim tim, ovaj rad će biti fokusiran na višestrane istorijske uticaje koji su oblikovali institucionalni identitet ovog prostora sa posebnim fokusom na osmansko nasleđe Balkana kao formativno u pogledu utemeljenja određenih institucija koje i danas utiču na razvoj balkanskih država. S tim u vezi, u radu će kao studija slučaja biti analizirana knjiga Halila Inaldžika „Osmansko carstvo - klasično doba 130o16oo” kao adekvatan prikaz potencijala istorijskog institucionalizma u objašnjavanju institucionalnih specifičnosti balkanskog područja. Na taj način se dobija slika Balkana kao konstrukcije zasnovane na viševekovnom, mnogostranom istorijskom nasleđu.
\end{abstract}

KLJUČNE REČI: istorijski institucionalizam, Balkan, Osmansko carstvo, institucije, Halil Inaldžik

\section{Kontakt autora:}

Dušan Čorbić, student doktorskih studija na Fakultetu političkih nauka Univerziteta u Beogradu.

E-mail: dusancorbic@gmail.com

1 Rad je nastao u okviru projekta „Politički identitet Srbije u regionalnom i globalnom kontekstu", br. 179076 . 


\section{UvoD}

U atmosferi institucionalne nestabilnosti balkanskih država, istorijski institucionalizam se izdvaja kao pogodan instrument za objašnjenje kroz analizu kritičnih tačaka koje su omogućavale ukorenjivanje institucija i praksi usled kojih je ometano uspostavljanje stabilnog i trajnog demokratskog, institucionalnog poretka. U nameri da rasvetli funkcionisanje država, istorijski institucionalizam je u međuigri istorijskog ambijenta i institucionalnog razvoja, koji iz njega proizlazi, pokušao da pruži adekvatne odgovore i objašnjenja u vezi sa delovanjem državnih struktura. Shodno tome, kao jedan od najuticajnijih pravaca u okviru novog institucionalizma, istorijski institucionalizam je doživeo pravu ekspanziju, naročito u oblasti političkih nauka.

U nastavku rada će biti razmatran balkanski prostor kao plodno tle za primenu istorijsko-institucionalnog pristupa. Najpre će se prikazati teorijski okvir na osnovu kojeg će se analizirati balkanska dešavanja. Primenjivanje istorijskog institucionalizma na područje Balkana poslužiće kao osnova za uočavanje i objašnjenje glavnih problema ovog prostora, u prvom redu otežanosti demokratske konsolidacije balkanskih država. Drugim rečima, biće prikazan današnji institucionalni deficit kao posledica istorijski uslovljenog razvoja institucija, čime se pruža mogućnost za uočavanjem fundamentalnih istorijsko-institucionalnih načela. Poseban akcenat $u$ radu je stavljen na istorijske okolnosti koje su uticale na formiranje određenih institucija značajnih za dalji razvoj balkanskih društava. Na kraju, u cilju obuhvatnijeg prikaza problema, analizom tvrdnji iz knjige „Osmansko carstvo 1300-160o”, eminentnog turskog istoričara Halila Inaldžika (Halil İnalcık), autor će nastojati da na indirektan način, kroz prikazivanje funkcionisanja Osmanskog carstva kao faktora koji je presudno oblikovao institucionalne obrasce Balkana, potkrepi izneti stav.

\section{ISTORIJSKI INSTITUCIONALIZAM - KLJUČNE POSTAVKE}

Istorijski institucionalizam se razvio iz neoinstitucionalnog pokreta koji je tokom osamdesetih godina XX veka postao jedan od najdominantnijih pristupa u društvenim naukama, naročito vezan za sociologiju i političke nauke. Hol (Peter A. Hall) i Tejlor (Rosemary C. R. Taylor) uvode u okviru novog institucionalizma podelu na tri tipa institucionalne analize: istorijski institucionalizam, sociološki institucionalizam i institucionalizam racionalnog izbora, od kojih se svaki usredsređuje na „određene situacije i gleda na svoj specifični način kakav učinak imaju institucije i ljudske aktivnosti" (Hall, Taylor 1996, 955-957 citirano u: Mataković 2014, 2). U ovoj grupi neoinstitucionalnih pokreta istorijski institucionalizam se ubrzo 


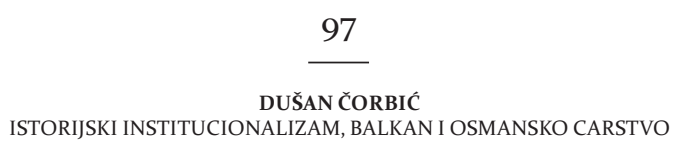

izdvojio kao izrazito popularan i uticajan pokret pogodan za objašnjenje brojnih društveno-političkih fenomena.

Suštinski, istorijski institucionalizam „proučava kako institucionalni odabiri koji su izvršeni u ranoj fazi razvoja određenog područja javnih politika kasnije ograničavaju odluke o politikama" (Lowndes 2005, 97). Drugim rečima, kako principi i vrednosti na kojima su prvobitno zasnovane i izgrađene institucije usmeravaju dalji razvoj tih institucija i na taj način presudno determinišu odabir politika. Važnost istorijskog momenta ogleda se kroz vremenski kontekst koji stvara i oblikuje date institucionalne aranžmane.

Institucije se, prema tome, mogu definisati kao istorijski proizvodi koji postoje pre svakog aktera, čije je delovanje u njima u bilo kojem trenutku slučajno (Blyth 2005, 294). Marč (James G. March) i Olsen (Johan P. Olsen) definišu institucije kao „relativno postojan skup pravila i organizovanih praksi koji je ugrađen u strukture značenja i resursa, koje su same relativno nepromenljive s obzirom na smenu pojedinaca i relativno otporne na idiosinkratične preferencije, očekivanja pojedinaca i promenljive spoljašnje okolnosti” (Marč, Olsen 2010, 247). Akteri definišu svoje preferencije u skladu sa kontekstom koji institucija pruža, što onemogućava racionalno delovanje (Mataković 2014, 3-4). Na taj način se upada u zamku rutinskog sleđenja i izvršavanja procedura i pravila bez kritičkog promišljanja o njihovoj valjanosti. Shodno tome, važno je definisati i institucionalni aranžman kao kombinaciju formalnih ograničenja i neformalnih pravila i njihovih karakteristika sprovođenja (North $2005 \mathrm{u}$ : Williamson 2009, 372).

Potrebno je istaći da tako shvaćene institucije uključuju izvestan stepen diskriminativnog ponašanja, odnosno privilegovanje interesa jedne grupe na uštrb drugih (Mataković 2014, 4). Taj stav je značajan ako imamo u vidu predstojeću analizu balkanske problematike. Naime, konstantna institucionalna diskriminacija etno-religijskih grupa kroz istoriju je u određenoj meri oblikovala karakter današnjih balkanskih društava.

Iz povezanosti istorijskog konteksta i institucija proizlazi i ključna odrednica istorijskog institucionalizma - stvaranje politika zavisi od „prethodno izabranog puta", to jest prvobitni institucionalni odabiri usmeravaju i ograničavaju kasnije odluke o politikama sužavajući mogućnost izbora (Krasner 1984 u: Lowndes 2005, 97; Pirson 2017). Reč je o koncepciji koja se zasniva na dve ključne postavke od kojih se prva odnosi na kritične trenutke kao tačke grananja koje usmeravaju istorijski razvoj na novi put, nakon čega je teško promeniti smer, dok druga postavka ističe značaj promene okolnosti na razvoj institucija, naglašavajući da on prati smer koji je presudno determinisan već pređenim putem. Dakle, prva postavka ima diskontinuitetno obeležje, dok se druga usredsređuje na kontinuitet (Mataković 2014, 6-7). Ovakav pristup ima za cilj pružanje sveobuhvatnijeg ugla sagledavanja i razumevanja institucionalne geneze i razvoja. 


\section{8 \\ POLITIČKE PERSPEKTIVE}

ČLANCI I STUDIJE

Glavni problem istorijskog institucionalizma svodi se na poteškoće u objašnjavanju promena. Ovaj problem istorijski institucionalisti su pokušali da prevaziđu kroz navedene evolucione modele, ali i kroz uvođenje pojmova ograničene inovacije i punktuiranog ekvilibrija. Ograničena inovacija podrazumeva situaciju u kojoj određene institucije istovremeno stvaraju i ograničavaju uslove za neke vrste inovacija (Weir 1992 u: Mataković 2014, 4-5), dok model punktuiranog ekvilibrija insistira na dramatičnim trenucima ili kriznim periodima koji kanališu institucionalne transformacije uvodeći nove ideje u institucionalni oblik (Krasner $1984 \mathrm{u}$ : Lowndes 2005, 101). Takođe, novi okvir za objašnjenje problema promena u okviru istorijsko-institucionalnog pristupa predstavlja kombinacija ideja i institucija kao adekvatan model za potpunije i jasnije sagledavanje datih problema. Pokazujući kako ideje utiču na promenu pojedinačnih interesa, Šeri Berman (Sheri Berman) objašnjava i način na koji ideje izazivaju promene u istorijski utemeljenim institucijama (Sheri Berman 1998, u: Blyth 2005, 301).

Najzad, potrebno je iskoristiti modele ekstraktivnih i inkluzivnih ekonomskih i političkih institucija kao adekvatne u kontekstu objašnjenja balkanskog institucionalnog razvoja. Inkluzivne ekonomske institucije nude bezbednost privatne svojine, nepristrasni pravni sistem, javne usluge koje obezbeđuju ravnopravnost u razmeni i pregovaranju čime se omogućuje učešće širokih masa u ekonomskim aktivnostima. Na taj način najbolje dolaze do izražaja talenti i sposobnosti pojedinaca. Na tom tragu, inkluzivne političke institucije karakteriše centralizacija i pluralizam. Sinergetski odnos inkluzivnih ekonomskih i političkih institucija stvara ravnotežu koja onemogućava nosiocima vlasti uspostavljanje ekstraktivnih ekonomskih institucija u svoju korist. S druge strane, inkluzivne ekonomske institucije stvaraju ravnomerniju raspodelu resursa i na taj način omogućavaju trajnost inkluzivnih političkih institucija. Kao sušta suprotnost ovakvom određenju inkluzivnih institucija stoje ekstraktivne ekonomske i političke institucije kao dominantni obrasci balkanskog institucionalnog razvoja (Asemoglu, Robinson 2014, 87-95).

\section{BALKAN - EVROPSKA TURSKA ILI OSMANSKA EVROPA}

Budući da se ovaj rad u najvećoj meri bazira na uticaju koji je Osmanska imperija imala na razvoj političkih institucija na Balkanu, tako je i prostorni obuhvat rada diktiran istorijskom pripadnošću osmanskom političkom i kulturnom krugu. Dakle, reč je o onom delu Balkana koji je bio uključen u osmanski upravni sistem, odnosno prostor „na kome je islamska civilizacija u njenoj osmanskoj varijanti uspela da zaživi zajedno sa svojim kulturnim vrednostima" (Kocić 2017, 9).

Samim tim, bez ulaženja u različita geografska određenja Balkana, ovaj rad će biti ograničen na navedenom istorijskom kriterijumu, sledeći klasi- 
fikaciju Marije Todorove koja u balkanske narode ubraja Grke, Albance, Bugare, Rumune ${ }^{2}$ i bivše Jugoslovene (uz izuzetak Slovenaca) ${ }^{3}$, imajući u vidu njihovu osmansku prošlost. Takođe, s obzirom na tematiku rada važno je pomenuti i savremenu Tursku. S tim u vezi, „neki turski istoričari naglašavaju da je otomanska država nastala kao balkansko carstvo, da je Balkan sve vreme bio prioritet Osmanskog carstva, i da zbog svog istorijskog kontinuiteta moderna Turska jeste balkanska država" (Todorova 2006, 94-124).

\section{ISTORIJSKA USLOVLJENOST INSTITUCIONALNOG RAZVOJA BALKANA}

Čini se da istorijsko-institucionalnom literaturom dominiraju zapadno-demokratski modeli, zanemarujući potencijalno zanimljive južnoevropske, balkanske slučajeve (Hopkin 2005, 259). Analiza Balkana i njegovih društava obično počinje i završava se isticanjem njegove dinamičnosti izražene kroz susrete različitih civilizacija $\mathrm{u}$ istoriji, pa samim tim i mešavine različitih naroda, vera i kultura koje su dale svojevrstan pečat ovom prostoru. Takva analiza često polazi od istorijskih pretpostavki koje osmanskom periodu ovog dela Evrope daju prevashodnu ulogu u procesu reprodukcije linija podele. Iako je to u načelu tačno, balkansko iskustvo treba sagledavati iz šireg ugla koji podrazumeva vekovnu horizontalu razvoja institucionalnih aranžmana, od primitivnijih slovenskih obrazaca do konkretnijeg vizantijskog i osmanskog uticaja. U toj ravni treba posmatrati i današnju konstrukciju ovog područja, kao i sve njegove probleme. Osmansko carstvo je značajno prvenstveno zbog činjenice da je u dugom periodu vladavine ovim prostorima uticalo na etabliranje i oblikovanje određenih institucija koje su u velikoj meri determinisale budući razvoj. Promene su bile površne pa je institucionalni izgled Balkana obeležen već usvojenim navikama.

Kao institucije čiji je uticaj i te kako primetan u razvoju balkanskih država treba posebno navesti vladara i crkvu. Istorijski sled događaja je, naročito osmanski period kroz sistem mileta, učinio crkvu najstabilnijom institucijom hrišćanskog stanovništva na Balkanu. Ovlašćenja vaseljenskog patrijarha nad pravoslavnim vernicima obuhvatala su, pored verskih,

2 Geografi obično smatraju Dunav severnom granicom Balkanskog poluostrva. Ipak, sa aspekta istorijskog razvoja, ta granica je neodgovarajuća jer isključuje rumunske zemlje čiji je razvoj bio sastavni deo balkanske istorije (Stavrianos 1958, 2).

3 Todorova među balkanske narode ubraja sve bivše Jugoslovene, napominjući da Slovence „ne bi trebalo uključiti među njih jer nikad nisu živeli pod otomanskom vlašću, dok Hrvate treba, budući da su značajni delovi teritorija naseljeni Hrvatima veoma dugo bili pod vlašću Otomana" (Todorova 2006, 94). 
i uređivanje brojnih stvari svakodnevnog života ${ }^{4}$ (Klog 20oo, 14). Crkva je u dugom periodu osmanske vlasti bila bedem hrišćanstva i očuvanja posebnosti hrišćanskih naroda Balkana, iz čega proizlazi njena značajna uloga u današnjem političkom životu svih balkanskih (većinski hrišćanskih) država. Tako je proces formiranja nacija najpre među hrišćanima, a kasnije i među muslimanima u Osmanskom carstvu bio u značajnoj meri uslovljen društveno-etničkom strukturom i verskim identitetom začetim u milet sistemu (Karpat 2017, 137). ${ }^{5}$ U kontekstu takvog uticaja verskih zajednica treba posmatrati i proces izgradnje nacije ${ }^{6}$ koji je na balkanskom tlu poprimio oblik „religijskog nacionalizma” (Bakić-Hayden 2006, 134-135).

Čvrst vladar i vladarska loza institucionalni je osnov koji su slovenska plemena prenela iz pradomovine. S tim u vezi, ilustrativno deluje podatak da je srpska zajednica pred osmansko osvajanje izgradila osnove identifikacije i da je u Osmansko carstvo ušla sa učvršćenim srpskim narodnim imenom, stvorenim jezgrom etničkog prostora, izgrađenim kultom svete loze Nemanjića kod svih društvenih slojeva, kojem će kasnije biti pridodato kosovsko predanje ${ }^{7}$ i srpsko pravoslavlje kao sinkretizam hrišćanskog učenja i nasleđenih kultova (Đorđević, Gavrilović 2006, 343-344; Popović 2007; Jovanović 2015). Karakterističan razvoj datih institucija (osmanskog) Balkana, pre svega crkve, imao je u narednim vekovima sveobuhvatan društveno-politički značaj.

4 Institucija etnarha (osmanski milet-baši) u Turskoj je postojala do 1923. godine, a na Kipru je bila otelovljena u liku prvog predsednika Republike Kipar, arhiepiskopa Makariosa III budući da je ovo crkveno zvanje po tradiciji iz osmanskih vremena spajalo u sebi ulogu verskog i svetovnog vođe kiparskih Grka. Bakić-Hejden navodi slučaj sarajevskih muslimana koji su pod habzburškom vlašću nakon 1878. godine funkcionisali kao nekad nemuslimanski mileti, tj. religijska zajednica. Na osnovu toga izvlači zaključak o kontinuitetu promene (Bakić-Hayden 2006, 151-155; Klog 2000, 232).

5 U tome se sastoji i temeljna razlika između pojave nacije u zapadnoj i jugoistočnoj Evropi. Nacija se na Zapadu pojavila naglašavajući jezičke i kulturne specifičnosti kako bi potvrdila kraljeva prava protiv crkvenih vlasti. Nasuprot tome, u jugoistočnoj Evropi hrišćanski narodi su tražili nezavisnost i nacionalnu državu naglašavajući svoju versku različitost $u$ odnosu na dominantne muslimanske vlasti. Shodno tome, nacionalnost se počela određivati prvo verskom pripadnošću, a tek nakon toga jezikom. Primera radi, Grk je označavao svakog pravoslavnog hrišćanina uključujući i Karamanliju koji je govorio turskim jezikom, ali je sebe smatrao Grkom (Karpat 2017, 143-185). Albanski nacionalni identitet, koji u velikoj meri odudara od takve definicije usled izrazite religijske heterogenosti, građen je na temelju jezičke posebnosti Albanaca (Bartl 2019).

6 Balkanske države su svoju crkvenu organizaciju, odvojenu od Vaseljenske patrijaršije, podredile nacionalnoj državi. Drugim rečima, religijski identitet je postao sastavni deo šireg i njemu nadređenog nacionalnog identiteta (Pavlović 2018, 68).

7 U potpunosti razvijen kosovski mit se javlja tek u 19. veku, tako što se starije priče o Kosovskom boju prekrajaju i dopunjuju kako bi mogle da služe, u to vreme aktuelnom, kultu nacije (Čolović 2016, 7). 
Navedene činjenice upućuju na složenost istorijskih faktora koji su, kao što je pomenuto, presudno oblikovali identitet čitavog podneblja. Tačnije, uzajamnost mnogobrojnih uticaja stvorila je dominantne institucionalne obrasce ovog područja. Kada govorimo o vizantijskom nasleđu Balkana tu uključujemo i paganske elemente koje je hrišćanstvo upilo prodirući u ruralna područja Balkana. S druge strane, u okviru osmanskog nasleđa uočljivi su dinamički procesi između starog, hrišćanskog i novog, islamskog nasleđa8 (Bakić-Hayden 2006, 148; Stojanović 1995, 19-20). Vizantijska civilizacija, koja je u vreme osvajanja u osnovi bila grčka, nastavljena je kroz grčku prevlast u Crkvi i kasniji fanariotski uticaj u institucijama Osmanskog carstva. Istovremeno, među proteranim i odbeglim stanovništvom, koje se našlo na mletačkim, ugarskim i habzburškim teritorijama, razvile su se složenije društvene strukture, kao posrednice između balkanskog sveta i ostatka Evrope (Pavlović 2018, 17-33). Prema tome, praksa je u slučaju balkanskih zemalja potvrdila stav da je kreiranje politika i te kako uslovljeno „prethodno izabranim putem”.

\section{EKSTRAKTIVNI INSTITUCIONALNI RAZVOJ}

Pomenuti modeli kritičnih trenutaka i promene okolnosti mogu se predstaviti kao adekvatan instrumentarij za objašnjenje institucionalnog karaktera Balkana. Primanje hrišćanstva, osmansko osvajanje i sticanje nezavisnosti balkanskih zemalja u 19. veku se, bez sumnje, mogu okarakterisati kao kritične tačke koje su usmerile istoriju na novi put, ali je promena istorijskih okolnosti i dalji razvoj u velikoj meri određen već pređenim putem koji je opstruisao nastanak i razvoj inkluzivnih institucija. Drugim rečima, etabliranost tradicionalnih institucionalnih obrazaca omogućavala je egzistiranje ekstraktivnih institucija koje su ometale kreiranje stabilnih i trajnih ustanova. Faktori koji ometaju napredak nalaze se upravo u dubokim slojevima tradicionalističke, patrijarhalne političke i društvene svesti koji, uz delovanje predmoderne političke kulture, predstavljaju prepreku stvaranju stabilnog demokratskog (institucionalnog)

8 Posebno su indikativni brojni primeri u sferi hagiolatrije. U Solunu je kult svetog Dimitrija poštovan kod hrišćana, muslimana i jevreja. Velika popularnost derviških redova na osmanskom Balkanu zasnivala se na tome što su zastupali narodnu religiju sa primetnim hrišćanskim i predhrišćanskim uticajima. Primera radi, većina derviških redova je negovala kult svetaca kojima su slavili kako hrišćanske svetitelje tako i predhrišćanska božanstva prilagođena novoj, islamskoj stvarnosti. Takođe, postojanje religioznih kalendara napravljenih po uzoru na kalendare i cikluse običaja vezanih za drevni paganizam govori u prilog tom istorijskom kontinuitetu. Prateći sudbinu najpoznatijeg vizantijskog hrama Aja Sofije, koja je po verovanju sagrađena na ruševinama bivšeg Apolonovog hrama, a 1453. godine, osmanskim osvajanjem Carigrada pretvorena u džamiju, Milica Bakić Hayden potkrepljuje navedeno stanovište o kontinuitetu promene na Balkanu (Mazover 2016; Bartl 2019, 57; Bakić-Hayden 2006, 148-150). 
poretka (Stojanović 2019, 419). S tim u vezi, naročito je slikovit stav da je balkanska narodna kultura do sredine 19. veka po svojoj suštini bila kultura preživelih oblika i anahronizama (Stojanović 1995, 23).

Na taj način je, paradoksalno, Balkan postao mesto preplitanja kontinuiteta i diskontinuiteta. Iako je javni diskurs insistirao na diskontinuitetu sa orijentalnim institucionalno-istorijskim okruženjem, dublja analiza nas neminovno dovodi do zaključaka koji ističu kontinuiran istorijski razvoj. Sve ono što je predstavljalo osmansko nasleđe bilo je odbačeno u procesu izgradnje nacije, izuzev značajnog, a nepriznatog društvenog i političkog mentaliteta (Pavlović 2018, 68; Bakić-Hayden 20o6; Todorova 2006). Takođe, važno mesto u analizi ovog tipa imaju i modeli ograničene inovacije i punktuiranog ekvilibrija, kao sredstva koja uz navedene modele pružaju jasniju sliku promene istorijskih i institucionalnih okolnosti. Insistiranjem na novim idejnim rešenjima koja u određenoj meri menjaju institucionalne oblike istovremeno se objašnjava i uticaj stranih sila i zapadnih ideologija na prirodu institucionalnog razvoja Balkana.

Kada je reč o istorijski uslovljenom razvoju institucija naročito je karakterističan slučaj Albanije. Odsustvo efikasne centralne vlasti, jednim delom, može se objasniti istorijskim nasleđem koje je obeleženo plemenskom, verskom i jezičkom diferencijacijom. ${ }^{9}$ Činjenica da ni Osmansko carstvo nije uspevalo ili je imalo teškoće da uspostavi kontrolu u određenim delovima Albanije govori u prilog tome. Opstajanje normi nepisanog običajnog prava (Zakon Leke Dukađina) u nekim krajevima severne Albanije svedoči o snazi i utemeljenosti nasleđenih ustanova. Takođe, kao posledica verskih razlika, koje su i same produkt navedenih istorijskih kretanja $^{10}$, padom komunističkog režima devedesetih godina, neformalno je uspostavljeno konsocijativno rešenje podele vlasti prema verskim kriterijumima"1 (Bartl 2019; Abrahams 2019; Pavlović 2018).

Takođe, kao indikativan primer može poslužiti i slučaj pokroviteljsko-klijentelističkih odnosa u Grčkoj utemeljenih u tradicionalnim, nefor-

9 Treba navesti da su se jezičke razlike, odnosno dijalekti gega i toska koji su se govorili u severnom, odnosno južnom delu Albanije, poklapali sa verskim razlikama budući da su pravoslavci i bektašije govorili toska, a suniti i katolici gega dijalektom. Standardizacijom jezika (uglavnom prema toska dijalektu, na nezadovoljstvo gega govornika), izvršenom za vreme vlasti Envera Hodže (Enver Hoxha), ova razlika je neutralisana (Bartl 2019, 16-246; Merdjanova 2013, 149-150).

10 Primer Albanije, ali i ostalih balkanskih zemalja upućuje na razmatranje uloge sistema mileta u očuvanju etničkog i jezičkog identiteta različitih grupa. Kemal Karpat navodi da bi detaljnija analiza turbulentne istorije Srbije i kasnije federalne Jugoslavije omogućila prepoznavanje uticaja sistema mileta (Karpat 2017, 187).

11 Otuda je predsednik države Sali Beriša bio musliman, premijer Aleksandar Meksi pravoslavac, a predsednik skupštine Pjeter Arbnori katolik (Abrahams 2019). 
malnim institucijama rusfete i mesa. Analizirajući ove ustanove, Ričard Klog (Richard Clogg) (2000: 65) navodi:

„Pokroviteljstvo se prvobitno razvilo kao neka vrsta odbrambenog mehanizma pred strogošću i, naročito, samovoljom osmanskog sistema vlasti. U tim okolnostima, pojedinac je osećao potrebu za pokroviteljima i zaštitnicima koji su mogli da posreduju kod osmanskih vlasti i ublaže hirovitost osmanskog sudstva. Mnogi Grci smatrali su obaveze koje je nametala nova država jedva nešto manje ugnjetačkim od osmanskih, pa su vrednosti i stavovi uobličeni pod osmanskom vlašću nastavili da žive i u razdoblju nezavisnosti. Štaviše, pokroviteljstvo se sasvim lepo uklopilo u zvanične ustanove parlamentarne demokratije. Mesni komatarhis („partijski vođa”) jednostavno je preuzeo ulogu osmanskog age. Sve do najnovijih vremena, skupštinski poslanici shvatali su deljenje privilegija svojim glasačima ne samo kao svoju obavezu nego i kao nužan preduslov političkog opstanka."

\section{OSMANSKI INSTITITUCIONALNI POREDAK} IZ UGLA HALILA INALDŽIKA

Prateći navedene teorijske modele dobijamo kompletniju sliku balkanske problematike. U predstojećem delu rada biće izložen istorijsko-institucionalni pristup na osnovu knjige „Osmansko carstvo 1300-160o” Halila Inaldžika, koja argumentuje iznete tvrdnje u korist ovog pristupa. Zarad veće preciznosti, određene postavke Inaldžikove studije biće dopunjene dodatnim pojašnjenjima drugih autora. S obzirom na to da je reč o dosta širokoj tematici osmanskog institucionalnog poretka, izabrana studija jednog od najpoznatijih turskih istoričara predstavlja pokušaj da se pruži kratak i jasan pregled istorijski uslovljenog razvoja osmanskih institucija. Kroz njihovu strukturu, genezu i razvoj indirektno će biti prikazana korelacija sa balkanskim prostorom, kao primarnim područjem ove analize.

\section{INSTITUCIONALNI KONTINUITET}

Studija „Osmansko carstvo - klasično doba 130o-16oo”, autora Halila Inaldžika, prikazuje nastanak, razvoj i propast Osmanskog carstva kao posledicu preuzimanja tradicionalnih institucija Bliskog istoka, njihovog unapređivanja, ali i fanatičnog držanja. Drugim rečima, „osmanska administrativna i birokratska praksa bila je izdanak i produžetak drevnih tradicija preislamskih država na Bliskom istoku” (Inaldžik 1974, 142).

Inaldžik tvrdi da osmanske institucije nisu bile nikakva novina pa ih tako oslobađa eventualne autentičnosti. One su samo primena bliskoistočnih, u prvom redu abasidskih, persijskih i vizantijskih tradicija. Tako su i dve bazične institucije Osmanskog carstva - robovski i timarski sistem, zapravo proizvod viševekovne bliskoistočne državne prakse. Timarski 
sistem $^{12}$ može se tumačiti kao nastavak i modifikacija vizantijske institucije pronije, odnosno „u oblastima pod neposrednom osmanskom administracijom, ta imanja (pronije) su ponovo potpala pod državnu kontrolu i pretvarana su u timare, ili su kao nagrada za vojne zasluge razdeljivane jajama, turskim zemljoradnicima koji su služili u vojsci kao pešaci”. Takvo stanje su Osmanlije zatekle i na Balkanu, usled čega im je bilo jednostavno da velika imanja u vlasništvu hrišćanskih gospodara pretvore u timare (Inaldžik 1974, 19-152). ${ }^{13}$

Centralizacija, kao važna karakteristika bliskoistočnog tipa države, bila je glavna težnja osmanskih vladara. $\mathrm{O}$ toj konstantnoj centrifugalnoj tendenciji istočnjačkog duha svedoči i podatak da je „Mehmed Osvajač tvrdio da u svojoj ličnosti sjedinjava islamsku, tursku i rimsku tradiciju u jedan univerzalni suverenitet" (Inaldžik 1974, 81). To upućuje na navedene teorijske postavke o kontinuitetu razvoja determinisanog već pređenim putem.

Međutim, centralizaciju u Osmanskom carstvu treba posmatrati kao sinkretističku formu centralizacije i autonomije verskih grupa, poznatiju kao sistem mileta. Može se pretpostaviti da je institucija mileta ${ }^{14}$ zapravo modifikacija nekih ranijih turskih i islamskih modela tolerantnog tretiranja drugoga. ${ }^{15}$ Islamskim zakonom i praksom, odnos muslimanske države i nemuslimanskih zajednica koje su imale određenu zaštitu i prema kojima se postupalo tolerantno uređivao je ugovor pod imenom zimma (Braude, Lewis 2017, 17). S druge strane, osmansku versku tolerantnost potvrđuje opstajanje njihovih starih verskih elemenata u kombinaciji sa islamom. Takođe, neke od najuticajnijih derviških grupa u sunitskom Osmanskom carstvu bile su pod snažnim uticajem šiizma i istočnog misticizma (Inaldžik 1974). Institucija mileta je glavni uzrok moći i ugleda pravoslavnih

12 Osmanski feudalni poredak ili timarski sistem se od evropskog feudalizma razlikovao po jakoj centralizovanoj kontroli i odsustvu hijerarhije i vazalskog odnosa (Inaldžik 1974, 162).

13 Timarska uprava i porezi vezani za nju su dugo određivani kao osobenost osmanskih privrednih odnosa. Ipak, prema nalazima istoričarke Dušanke Bojanić-Lukač, veličina osmanskog poreza ispenč naplaćivanog od hrišćana, po veličini i sadržaju, poklapa se sa porezom dimnina koji je na Balkanu poznat pre dolaska Osmanlija (Bojanić-Lukač 1969, u: Georgijeva 2008, 137). Zarad brzog i efikasnog korišćenja njihovih ekonomskih potencijala, osvajači su u potpunosti preuzeli lokalnu proizvodnu tradiciju čije je jezgro bilo seosko gazdinstvo koje formira osnovnu poresku jedinicu hane. Veličina poreske obaveze je zavisila od veličine ličnog gazdinstva, a njegov naziv je bukvalan prevod vizantijskog termina zevgar (Georgijeva 2008, 137).

14 Postoji stav da sistem mileta nije bio institucija već pre skup aranžmana, pretežno lokalnih, sa brojnim varijacijama kroz prostor i vreme (Braude 2017, 116).

15 Milet sistem je svoje islamske korene dugovao samim počecima islama, odnosno događajima iz Muhamedovih medinskih godina (622-632), kada je većinsko muslimansko stanovništvo tog grada moralo da razmotri pitanje odnosa većinske muslimanske zajednice prema manjinama (Bosworth 2017, 73). 
crkava u balkanskim zemljama. U periodu osmanske vlasti one su bile glavni čuvar srednjovekovnog nasleđa i posebnosti ovdašnjih naroda. Stečeni legitimitet, zahvaljujući postojanju institucije mileta, odredio je dalji put, uticaj i moć crkvama balkanskih naroda.

U državi Bliskog istoka, deljenje pravde je bio najvažniji zadatak Porte, otuda je ova institucija uz sultana, imala najveći legitimitet u Osmanskom carstvu (Inaldžik 1974, 126). Pravni poredak Carstva je dosta složeniji od isključive primene šerijatskog prava kako se često pretpostavlja. U skladu sa „persijskim državnim tradicijama, pravda se shvata kao suverenova milost $\mathrm{i}$ naklonost koje proističu iz njegove apsolutne vlasti, dok pravičnost vladavine u krajnjoj liniji zavisi od vladarevih moralnih osobina" (Inaldžik 1974, 94). Stav persijskog kralja Hozroja I najpreciznije odslikava prirodu bliskoistočne države: „Pod pravednom i umerenom vladom narod će više proizvoditi, prihodi od dažbina će se uvećati, a država postati bogata i moćna. Pravda je temelj snažne države" (Inaldžik 1974, 93). Pored ovakvog shvatanja pravde, treba pomenuti i turske tradicije vezane za centralnu Aziju koje pravdu svode na nepristrasno primenjivanje torua ili jase, zbornika zakona koji je bio primaran pre primanja islama. Prema ovom zborniku, idealna vlast je ona vlast koja se u svemu pridržava torua, iz čega sledi da su „vladarski suverenitet i toru nerazdvojni pojmovi” (Inaldžik 1974, 93). Činjenica da je toru preživeo primanje islama i ostao važno uputstvo za vođenje države govori o snazi prihvaćenih institucija. Takođe, govori i u prilog navedene istorijsko-institucionalne postavke o razvoju određenom pređenim putem.

Toru je, prema tome, uticao i na zakonodavstvo Osmanskog carstva (Kanun-name), ali i na brojne institucionalne mehanizme. Preciznije, „osmanska koncepcija države, iako u osnovi vodi poreklo sa drevnog Bliskog istoka, trajno je sačuvala izvesne turske tradicije" (Inaldžik 1974, 95). U kontekstu balkanskih naroda, osmanske vlasti su dozvolile egzistenciju tradicionalnih zakona, običaja i institucija, što je uticalo da neke od tih procedura prežive do danas, bilo u vidu neformalnih obrazaca prisutnih u narodnoj svesti, bilo kao preživeli segmenti širih, institucionalizovanih procedura. Takođe, tradicionalno zakonodavstvo i institucije Balkana imale su reverzibilan uticaj, ulazeći postepeno u osmanski pravni poredak. Osmanski kanun je često dopunjavan običajnim pravom i ponekom pravnom ustanovom pokorenog naroda koje nisu bile u suprotnosti sa šerijatom. Tako je preuzet srpski rudarski statut, propisi o vlaškoj organizaciji, lokalnoj upravi i određenim dažbinama (obručina, gospoština, počepina, gornina, poklon i druge) (Zirojević 2018, 55-80; Inaldžik 1974, 101).

Vladar, ili preciznije sultan, je najstabilnija institucija sa najvećim legitimitetom u osmanskoj državi. Osmanska vlast je predstavljala sultanovo pravo da upotrebljava i štiti sve izvore dobara i održava harmoniju među 
društvenim staležima i miletima (Pavlović 2018, 16). Za prikazivanje ove institucije Inaldžik navodi indo-persijsko delo „Ogledalo za prinčeve”, gde se vladar upoređuje sa pastirom, a njegovi podanici sa stadom: „Bog poverava podanike pastiru da bi ih štitio i vodio pravim putem, a podanici su dužni da bez pogovora slušaju svog suverena”. U skladu sa tim, „teorija halifata kakvu su zastupali muslimanski pravnici u mnogim vidovima se podudara sa drevnom teorijom države Bliskog istoka" (Inaldžik 1974, 95). Ovakav paternalistički tretman vladara je (bio i) ostao dominantan način razmišljanja na svim teritorijama osmanske vlasti, uključujući i Balkan za koji se ovakve tradicije vezuju za dosta ranije (preosmanske) periode. ${ }^{16}$ Takva nasleđena politička kultura, u odsustvu kritičnih tačaka koje bi promenile dato stanje, predstavlja značajnu prepreku demokratizaciji većine zemalja postosmanskog prostora.

\section{EKSTRAKTIVNE INSTITUCIJE I PROPAST OSMANSKE IMPERIJE}

Kao što je rečeno, osmanska birokratska praksa je izdanak i produžetak države Bliskog istoka, i kao takva je ispoljavala sve slabosti koje su se mogle sresti u datim društvima. Kako se širila država tako se povećavala birokratija i stepen ekstrakcije, a samim tim i problemi inherentni za takav tip države. Poput Vizantije, koja je u poznoj fazi svog postojanja patila od korupcije, tako je i u slučaju Osmanskog carstva ona bila znak postepene propasti. Po oceni turskih pisaca, korupcija, to jest mito je bio jedan od glavnih uzroka slabljenja državne organizacije i administracije ${ }^{17}$ (Inal-

16 Kult vođe, karakterističan za sve balkanske države, posebno odslikavaju muzeji posvećeni liderima ovdašnjih zemalja. U tom kontekstu je indikativan slučaj najuticajnijeg grčkog političara prve polovine 2o. veka Elefteriosa Venizelosa. U muzeju liberalnog kluba u Atini koji predstavlja svojevrstan hram posvećen uspomeni na Venizelosa, čuvaju se sa najvećim poštovanjem izrešetana kola u kojima je preživeo atentat 1933. godine, kao i njegova dopola popušena cigara. Takođe, jedna dopisnica iz 1920. godine prikazuje Venizelosa uz Isusa Hrista ispod čije predstave stoji natpis „Hristos nebeskom ocu”, dok ispod Venizelosove stoji „I ja zemaljskom ocu”. Slikovit je i slučaj jednog odraza pred izbore 1981. godine u Grčkoj gde je ulazak budućeg premijera Andreasa Papandreua u Patras upoređen sa Hristovim ulaskom u Jerusalim na Cvetnu nedelju (Klog 200o, 105-187). U literaturi se često stil vlasti kneza Miloša Obrenovića poistovećuje sa stilom osmanskog paše, odnosno „Milošev politički mentalitet ostao je mentalitet jednog turskog paše" (Pavlović 2018, 80). Živojin Perić, srpski pravnik i političar, ilustrativno prikazuje kult vođe kod Srba rečima: „Srpski je narod sviknuo od vajkada, i to mu je prešlo u krv, da svoga vladara vidi kao uzvišenoga, sjajnog, moćnog i očinski vezanog sa njim. On voli da u njemu gleda sjaj svoje otadžbine, najvišu moć zakona i pravde, oca" (Živojin Perić 1910, citirano u: Stojanović 2019, 103).

17 O tome sredinom 17. veka osmanski letopisac Mehmed Halifa Bošnjak svedoči: „Do umanjivanja prihoda i uvećavanja rashoda dolazilo je stoga što je bilo mnogo janjičara. A mnoštvo janjičara prouzrokovalo je da se pašama i begovima daju službe uz mito. A kad se daju položaji uz mito janjičarima ne dostiže za plaću. Kad nema plaća za janjičare, onda oni 
džik 1974, 68). Složena birokratska praksa praćena korupcijom ostala je glavno institucionalno nasleđe svih država postosmanskog prostora, što nas upućuje na ranije navedenu kategoriju ekstraktivnih institucija. ${ }^{18}$

Iz perspektive istorijskog institucionalizma, odnosno etabliranosti ekstraktivnih institucija možemo analizirati i propast Osmanske imperije. Iako Inaldžik navodi da su se institucije i ustrojstvo carstva menjali u skladu sa promenama okolnosti u određenim razdobljima, problem fanatičnog držanja tradicionalnih ekstraktivnih institucija Bliskog istoka i nespremnost za radikalnom promenom institucionalnih mehanizama bliskoistočnog tipa doveo je u krajnjoj liniji do propasti države. Preciznije, „većina pisaca se rukovodila tradicionalnim konceptima države i društva na Bliskom istoku, prema kojima su država i vladarev suverenitet jedan pojam. Oni su podržavali one institucije koje su garantovale integritet $\mathrm{i}$ apsolutni karakter takve vlasti. Rešenja koja su predlagali nisu prevazilazila okvire takve koncepcije, a preduzete mere dale su ishod suprotan postavljenom cilju. Ne obazirući se uopšte na izmenjene okolnosti, tvrdili su da će se oživljavanjem „starih zakona i regula” - što će reći klasičnih osmanskih institucija - proces opadanja zaustaviti" (Inaldžik 1974, 69). Kontraproduktivno, klasične osmanske institucije su se raspadale u sudaru sa novom Evropom usled nemogućnosti Osmanlija da se prilagode izmenjenim okolnostima, zbog čega su i institucionalne reforme ostale sputane „tradicionalnim klišeima države Bliskog istoka" (Inaldžik 1974, 74). Do raspada je došlo usled odsustva kritične tačke koja bi transformisala i preusmerila osmanski ekstraktivni institucionalni poredak na nov pravac razvoja inkluzivnih institucija. Iako na prvi pogled deluje da je Mladoturska revolucija (ili čak raniji reformatorski pokušaji) imala potencijal da sprovede to preusmeravanje, dalji tok događaja demantovao je takve mogućnosti.

Preuzimanje i prilagođavanje starih imperijalnih institucija izgradiće identitet ovog Carstva, preko kojih će ono uticati na sve teritorije svoje

krenu na dvor i bez razloga mrcvare. Sada su vodeći ljudi države, da bi se spasili nevolje, davali položaje uz mito. Oni koji su službu dobili potkupljivanjem, a onda nakon tri meseca udaljeni iz službe, mnogo su mučili narod kako bi povratili novac i poklone koje su dali. A narod koji nije mogao izdržati poreze koji su prelazili svaku granicu bio je prisiljen bježati u neprijateljske zemlje, čime su pokrajine postale puste i zapuštene" (citirano u: Zirojević 2018, 49-50).

18 Korupcija nije bila rezervisana samo za muslimanske prvake, već je bila prisutna i u okviru uticajne grčke fanariotske zajednice. Osmanske vlasti su uzimale ogroman mito za položaje vaseljenskog patrijarha i kneževa podunavskih kneževina (Vlaške i Moldavije) na koje su postavljale istaknute fanariote. Da bi nadoknadio finansijske gubitke kojim je obezbedio svoj položaj, vaseljenski patrijarh je po stupanju na dužnost takođe morao da uzima mito, čime je i sama crkva tonula u institucionalizovanu korupciju karakterističnu za osmanski sistem. Kasnija korupcija i nezgrapan birokratski aparat u samostalnoj grčkoj državi, vezan za institucije rusfete (politička podrška) i mesa (dobre veze), duguje svoj značaj osmanskom nasleđu. Pokroviteljsko-klijentelistički odnosi tipični za navedene institucije ostali su do danas upečatljivo obeležje grčkog društva (Klog 2000, 8-64). 
vlasti. Međutim, tradicionalne institucije će sputavati suočavanje sa radikalno izmenjenim okolnostima ${ }^{19}$, zbog čega će osmanska istorija postati „letopis o istrošenim oblicima starih imperijalnih institucija” (Inaldžik 1974, 8). To, naravno, ne znači da su smrću osmanske imperije umrli i pomenuti institucionalni obrasci, naprotiv, oni su nastavili da žive u izmenjenom obliku na postosmanskim prostorima i da utiču na politike tih zemalja, što je i navedeno u prethodnom delu o Balkanu kao osmanskom nasleđu. Dakle, propast Osmanskog carstva je zapravo kritičan trenutak, odnosno tačka koja je istoriju usmerila na nove pravce.

Prema tome, „na osnovu svega nameće se zaključak da su osnovni principi bliskoistočne teorije o državi ostali nepromenjeni i u osmanskim vremenima, uprkos uticaju šerijata i grčke političke misli. Osmansko uređenje bilo je zasnovano na tim principima, i oni se jasno ispoljavaju u svim njegovim upravnim telima, kao i u svim njegovim državnim poslovima” (Inaldžik 1974, 96).

\section{ZAKLJUČAK}

Na kraju ovog razmatranja može se zaključiti da je balkanski prostor izuzetno plodno tle za analiziranje i primenu istorijsko-institucionalnog pristupa. Takva analiza bi morala da bude sveobuhvatnija u smislu istorijskog opsega. Potrebno je temeljno razmatranje institucija tradicionalnih društava i na osnovu toga izvlačenje zaključaka o njihovom uticaju u funkcionisanju savremenih balkanskih država. Samim tim, ovaj rad se može okarakterisati kao prikaz potencijala ovog teorijskog pristupa u objašnjavanju brojnih balkanskih fenomena čije je važenje presudno u kontekstu razumevanja aktuelne problematike celokupnog balkanskog prostora.

Na osnovu izloženog može se primetiti uticaj društvenih obrazaca na stvaranje institucionalnih anomalija kao što je slučaj sa brojnim vidovima koruptivnih praksi. Reč je o višestrukim uticajima koji se ne mogu ograničiti samo na period osmanske vlasti, zbog čega bi institucionalni poredak savremenih balkanskih država trebalo posmatrati iz šire istorijske perspektive koja prevazilazi osmansko nasleđe. Ipak, osmanski uticaj na izgradnju, odnosno učvršćivanje određenih institucionalnih aranžmana je značajan usled dugog razdoblja prevlasti Osmanskog carstva na ovom prostoru.

Doba Osmanskog carstva, kao najupadljiviji i najuticajniji period balkanskog institucionalnog razvoja, zaslužuje posebno mesto u razma-

19 Reformski pokret (tanzimat) je pokušao da transformiše osmanski institucionalni poredak po uzoru na zapadni model, ali je pokušaj uspostavljanja inkluzivnog institucionalnog ambijenta opstruisan ukorenjenošću ekstraktivnih institucija. Neuspeh mladoturskih reformatorskih tendencija govori u prilog tome. Čak je i period kemalističke Turske obeležen konstantnom borbom sa čvrsto ukorenjenim osmanskim institucionalnim nasleđem (Tomić 1939). Ta zaostavština se prepoznaje i u praksi savremene turske države. 
tranju datih procesa. Otuda je taj period kroz prikaz knjige turskog istoričara Halila Inaldžika „Osmansko carstvo 1300-160o” označen kao formativan u procesu uobličavanja institucionalnih obrazaca koji su opredeljivali dalji put institucionalnog razvoja. Dati prikaz, fokusiran na nasleđeni institucionalni poredak Osmanskog carstva, indirektno postaje okvir za razumevanje mnogih pitanja balkanske problematike. Tako se brojna institucionalna rešenja i problemi balkanskih država mogu tumačiti kao posledica nasleđa osmanske vlasti. Preciznije, obrada knjige Halila Inaldžika zapravo je argument u prilog pristupa istorijskog institucionalizma kroz analizu institucionalnog života nekada moćne imperije. Istorijski institucionalizam pruža mogućnost za potpunije sagledavanje tog razvoja kroz teorijske koncepte koji omogućavaju razumevanje promenljivih okolnosti kao neminovnosti turbulentnog istorijskog toka. Na osnovu toga može se izvesti i sud o adekvatnosti i primenjivosti navedenih teorijskih komponenti ovog pristupa na datoj balkanskoj tematici.

\section{LITERATURA}

Abrahams, Fred. 2019. Savremena Albanija. Beograd: Clio.

Asemoglu, Daron i Robinson, A. Džejms. 2014. Zašto narodi propadaju: Poreklo moći, prosperiteta i siromaštva. Beograd: Clio.

Bartl, Peter. 2019. Albanci: Od srednjeg do kraja 2o. veka. Beograd: Clio.

Blyth, Mark. 2005. „Institucije i ideje”. U ur. David Marsh, Gerry Stoker. Teorije i metode političke znanosti. Zagreb: Fakultet političkih znanosti.

Bosworth, E. C. 2017. „Koncept zimme u ranom islamu”, U ur. Benjamin Braude, Bernard Lewis. Kršćani i jevreji u Osmanskoj carevini: funkcioniranje jednog pluralnog društva. Sarajevo, Beograd: Centar za napredne studije, Balkanski centar za Bliski istok.

Braude, Benjamin i Lewis, Bernard. 2017. „Kršćani i jevreji u Osmanskoj carevini: funkcioniranje jednog pluralnog društva: Uvod”. U ur. Benjamin Braude, Bernard Lewis. Kršćani i jevreji u Osmanskoj carevini: funkcioniranje jednog pluralnog društva. Sarajevo, Beograd: Centar za napredne studije, Balkanski centar za Bliski istok.

Čolović, Ivan. 2016. Smrt na Kosovu polju. Beograd: Biblioteka XX vek.

Đorđević, B. Dragoljub i Gavrilović, Danijela. 2006. „Srbija: Verska i etnička identifikacija između balkanske prošlosti i evropske budućnosti”. Kultura polisa, $4-5,3,339-346$.

Georgijeva, Cvetana. 20o8. „Osmanska vladavina u bugarskim zemljama”. U prir. Srđan Pirivatrić. Istorija Bugarske. Beograd: Clio.

Hayden, Bakić, Milica. 20o6. Varijacije na temu Balkan. Beograd: Institut za filozofiju i društvenu teoriju, Filip Višnjić. 
Hopkin, Jonathan. 2005. „Komparativne metode”. U ur. David Marsh, Gerry Stoker. Teorije i metode političke znanosti. Zagreb: Fakultet političkih znanosti.

Inaldžik, Halil. 1974. Osmansko carstvo 1300-160o. Beograd: Srpska književna zadruga. Jovanović, Bojan. 2015. Duh paganskog nasleđa. Beograd: Dereta.

Karpat, H. Kemal. 2017. „Milleti i nacionalnost: korijeni nepodudaranja nacije i države u postosmanskoj eri”, U ur. Benjamin Braude, Bernard Lewis. Kršćani i jevreji u Osmanskoj carevini: funkcioniranje jednog pluralnog društva. Sarajevo, Beograd: Centar za napredne studije, Balkanski centar za Bliski istok.

Klog, Ričard. 200o. Istorija Grčke novog doba. Beograd: Clio.

Kocić, Marija. 2017. Orijentalizacija materijalne kulture na Balkanu: osmanski period XV-XIX vek. Beograd: HERAedu.

Lowndes, Vivien. 2005. „Institucionalizam”, U ur. David Marsh, Gerry Stoker. Teorije i metode političke znanosti. Zagreb: Fakultet političkih znanosti.

Marč, G. Džejms i Olsen, P. Johan. 2010. „Elaboriranje 'Novog institucionalizma”, U prir. Petar Bojanić, Ivan Mladenović. Institucije i institucionalizam. Beograd: Službeni glasnik.

Mataković, Hrvoje. 2014. „Temeljne značajke historijskog institucionalizma”, Glasnik prava, 5, 2, 1-11.

Mazover, Mark. 2016. Solun grad duhova. Beograd: Dosije.

Merdjanova, Ina. 2013. Rediscovering the Umma: Muslims in the Balkans Between Nationalism and Transnationalism. New York: Oxford University Press.

Pavlović, K. Stevan. 2018. Istorija Balkana 1804-1945. Beograd: Clio.

Pirson, Pol. 2017. „Rastući prinosi, putna zavisnost i istraživanje politike”. Političke perspektive, 7, 1-2: 71-109. DOI: 10.20901/pp.7.1-2.05

Popović, Miodrag. 2007.Vidovdan i časni krst. Beograd: Biblioteka XX vek.

Stavrianos, S. Leften. 1958. The Balkans Since 1453. New York: Rinehart \& Company, Inc.

Stojanović, Dubravka. 2019. Srbija i demokratija 1903-1914. Beograd: Udruženje za društvenu istoriju.

Stojanović, Trajan. 1995. Balkanska civilizacija. Beograd: Centar za geopoetiku.

Todorova, Marija. Imaginarni Balkan. Beograd: Biblioteka XX vek.

Tomić, Sv. Zoran. 1939. Kamal Ataturk - tvorac nove Turske. Beograd: Planeta.

Zirojević, Olga. 2018. Iz osmanske baštine. Beograd: Balkanski centar za Bliski istok.

Williamson, R. Claudia. 2009. "Informal institutions rule: Institutional arrangements and economic performance”. Public Choice, 139, 3: 371-387. DOI: 10.1007/ S11127-009-9399-X 


\section{SUMMARY \\ Historical Institutionalism, THE BALKANS AND OTTOMAN EMPIRE}

The aim of this paper is to make an attempt to utilize historical institutionalism in order to approach the issue of the Balkans development, in order to explain institutional order in this region. Historical institutionalism can, therefore, be characterized as a suitable framework for understanding the specifics of the institutional development of the Balkan countries. Consequently, this paper will focus on the multifaceted historical influences that shaped the institutional identity of this region with a special focus on the Ottoman heritage of the Balkans, which had a role of establishing certain institutional patterns that still influence the development of the Balkan countries. In this respect, Halil İnalcık's book “The Ottoman Empire: 1300-160o” will be analyzed as a case study as an appropriate example how valuable historical institutionalism can be in explaining the institutional specifics of the Balkan region. This approach derives an image of the Balkans as a construction developed on centuries-old historical legacy marked by the influences of different civilizations, which ultimately contributes to a better understanding of the institutional design of the Balkan countries.

KEYwORDS: Historical institutionalism, The Balkans, Ottoman Empire, institutions, Halil İnalcık. 